\title{
Federalismo e direitos culturais indígenas: uma aproximação entre o federalismo canadense e o brasileiro
}

\author{
Federalism and indigenous cultural rights: an \\ approach between canadian and brazilian federalism
}

\author{
Voltaire de Freitas Michel ${ }^{*}$
}

\section{Resumo}

O artigo apresenta uma reflexão sobre o reconhecimento do valor constitucional dos costumes indígenas como fonte do Direito e os reflexos desse acolhimento na federação brasileira. A partir da análise do mesmo problema sob o prisma do Direito canadense, o trabalho explora as semelhanças e diferenças entre ambas as ordens jurídicas para chegar à conclusão provisória de que o tratamento conferido pela Corte Suprema do Canadá às normas jurídicas de origem tradicional ou espontânea, próprias dos povos indígenas, é compatível com o tratamento a ser conferido na própria ordem jurídica brasileira. Essa compatibilidade procede do fato de que os dispositivos constitucionais que protegem os direitos culturais indígenas e as regras de competência da federação brasileira assemelham-se às normas da federação canadense. Consideradas essas duas circunstâncias normativas, a conclusão é no sentido de que as normas tradicionais indígenas não podem ser alteradas ou mitigadas por normas estaduais ou municipais, não obstante a competência concorrente desses integrantes da federação, uma vez que a Constituição Federal atribuiu exclusivamente à União a competência para legislar sobre povos indígenas. Com essa conclusão, cria-se um espaço sui generis de exclusividade legiferante não estatal em favor dos povos indígenas, sujeitos apenas a eventuais restrições determinadas por legislação federal, em simetria com a solução encontrada no Direito canadense.

Palavras-chave: Direito constitucional. Federalismo. Direitos indígenas. Pluralismo jurídico. Direito comparado.

* Mestre e Doutor em Direito pela UFRGS. Professor de Filosofia Geral e Jurídica no Centro Universitário Ritter dos Reis. Promotor de Justiça no Rio Grande do Sul. Porto Alegre - RS Brasil. Email: voltairemichel@hotmail.com 


\section{Abstract}

The article presents a reflection on the constitutional recognition of the value of indigenous customs as a source of law and its consequences in the Brazilian federation. From the analysis of the same problem through the prism of Canadian law, the work explores the similarities and differences between the two legal systems, to get to the provisional conclusion that the treatment given by the Canadian Supreme Court to the indigenous norms of traditional or spontaneous origin is compatible with the treatment to be given in the Brazilian law. This support comes from the fact that the constitutional provisions that protect indigenous cultural rights and define the Brazilian federation resemble the Canadian federation standards. Considered these two normative circumstances, the conclusion is that indigenous traditional norms cannot be changed or mitigated by state or local regulations, despite the concurrent power to enact laws of members of the federation, since the Constitution has assigned exclusively to the Union the competence to legislate on indigenous peoples. With this conclusion, it creates a space sui generis of legislative exclusivity in favor of indigenous peoples at the end subject only to any restrictions to be determined by federal law in symmetry with the solution found in Canadian law.

Keywords: Constitutional law. Federalism.Indigenous rights.Legal pluralism. Comparative law.

\section{Introdução}

Poucos temas no Direito Constitucional absorveram de modo tão profundo, e tão rápido, as modificações sociais nos últimos dois séculos. Tomando o federalismo americano como ponto de partida, percebe-se uma evolução qualitativa no modo de repartição de competências legislativas, executivas e fiscais nos Estados que optaram por tal desenho institucional. Partindo do modelo dual americano, substancialmente transformado pela jurisprudência da Suprema Corte Americana, o século XX conheceu, após a $2^{\mathrm{a}}$ Guerra Mundial, novas modalidades de federação, destacando-se o federalismo de cooperação adotado na Lei Fundamental de Bonn, no Canadá e na Suíça. À 
margem do esquema federal, é de se destacar a experiência de Estados que, embora nominalmente unitários, praticam a descentralização, de modo que não seria demais qualificá-los como quase-federais, adotando modelos assimétricos de repartição de competências, como as experiências espanhola, italiana e francesa (CROISAT, 1992, p. 7). Isso sem falar nos processos de federalização, que, se não conduziram a um "Estados Unidos da Europa", como preconizado por Jean Monnet (CROISAT, 1992, p. 8), inspiram-se nos mesmos propósitos federalistas de convergência entre unidade e repartição de poderes.

A inspiração do federalismo é a convivência entre pelo menos dois núcleos legiferantes numa mesma base territorial, poder central e poderes periféricos, devidamente equilibrados. Melhor definindo, federalismo é a inspiração, a intenção e de repartir poderes, e a federação é a forma final que cada nação escolhe e define para montar seu esquema institucional (CROISAT, 1992, p. 16). Por trás da distribuição das competências legislativas, característica inerente dos federalismos modernos, há um pressuposto aparentemente indisputado que pode alienar do estudo das federações uma parte importante do fenômeno jurídico. Esse pressuposto é a centralização das competências legislativas no Estado. Nesse particular, a experiência da federação apenas reproduz uma característica própria do Direito moderno, qual seja, a sua tendência legolátrica ou legicêntrica, para empregar os neologismos de Paolo Grossi, que tão bem sintetizam a ideia (GROSSI, 2007, p. 78). O centro da produção legislativa é, sobretudo, o Estado.

A relação entre o ordenamento jurídico constitucional, que adota a federação como forma, e as demais fontes legiferantes, como as tradições indígenas, pode ocorrer de duas formas: ou a ordem jurídica acolhe as normas tradicionais e os costumes, emprestando-lhes legitimidade através de uma norma de sobredito, subordinando-os ao ordenamento positivo (abordagem continente); ou, por outra perspectiva, reconhece-se a concorrência em pé de igualdade entre fontes do direito, acolhendo-se uma perspectiva mais pluralista e igualitária (abordagem inerentista) (ASCH; MACKLEM, 1991, p. 498). 
O objetivo deste trabalho é avaliar em que medida o esquema federal, no Canadá e no Brasil, é capaz de absorver o pluralismo jurídico decorrente de fontes concorrentes do Direito, sobretudo pelo reconhecimento e proteção constitucional das tradições e costumes indígenas.

Além disso, o propósito do presente estudo é apresentar um fenômeno ocorrido na federação canadense - o qual poderia, sem obstáculos, ser transportado para a federação brasileira -, que é o reconhecimento dos direitos tradicionais indígenas como fontes do direito e, por extensão, seu impacto na estrutura federal.

O problema que se apresente é se o reconhecimento dos direitos tradicionais indígenas, protegidos constitucionalmente no Canadá e no Brasil, tem como consequência o surgimento de outro degrau na federação ou a mitigação de competência do poder central e dos poderes periféricos, como efeito inesperado da proteção constitucional desses direitos. O reconhecimento de uma esfera própria de legiferação, protegida da interferência de outros polos legisladores, representaria na federação brasileira uma consagração formal do princípio do pluralismo cultural a que alude Cunha Filho (2000, p. 45).

Na primeira parte do trabalho, será apresentado um esboço das características particulares da federação canadense e como a inserção da proteção dos direitos tradicionais impactou na competência legislativa da União e dos Estados.

Em seguida, o trabalho prossegue com uma apresentação das principais características da federação brasileira e como se insere o reconhecimento de direitos tradicionais no esquema federal.

\section{Federação e "First Nations" no Canadá}

O Ato Constitucional de 1982, a Constituição do Canadá, instituiu um sistema federativo semelhante ao adotado nos Estados Unidos e ao mesmo tempo atribuiu proteção constitucional aos usos e costumes 
dos povos indígenas originários, "First Nations", assim como aos Inuit e Métis.

$\mathrm{Na}$ ação de interpretar o texto constitucional, a Corte Suprema do Canadá liderou a transformação do cenário jurídico, moldando o perfil do reconhecimento constitucional das tradições indígenas, acolhendo os costumes e as tradições como fontes do direito. Além disso, a Corte definiu os limites constitucionais da proteção, esclarecendo em que circunstâncias o legislador poder restringir direitos indígenas (BORROWS, 2005, p. 167).

\section{a) Esquema institucional da federação canadense}

$\mathrm{Na}$ sua origem, a primeira integração entre as províncias canadenses, ainda vinculadas ao Império Britânico, ocorreu por lei do Parlamento Britânico, em 1867 (British North AmericaAct). Em 1931, por força do Estatuto de Westminster, reconheceu-se a independência do Canadá, permanecendo o vínculo da Commonwealth. Finalmente, em 1982, o Parlamento Canadense aprovou seu ato constitucional, incluindo uma Carta de Direitos e Liberdades e aperfeiçoando o seu modelo de federação.

No Canadá, o esquema federal foi inspirado, em parte, no modelo dual norte-americano. Na federação americana, a Constituição definiu, inicialmente, competências exclusivas da União, no seu art. $1^{\circ}$, seção oitava, incluindo, sobretudo, as relacionadas com a integridade territorial e a defesa externa. A Emenda Constitucional $n^{\circ} 10$, por seu turno, atribuiu aos Estados todas as competências remanescentes não atribuídas ao Congresso nem proibidas aos Estados. Na sua origem, o federalismo americano apresentava um caráter dual e rígido, delimitando claramente as competências do poder central e dos poderes periféricos. Embora não seja o propósito específico deste trabalho, é importante acentuar que esse esquema rígido e dual já foi bastante mitigado por sucessivas decisões da Suprema Corte Americana, no sentido de interpretar extensivamente cláusulas de competência exclusiva da União (TRIBE, 2000, p. 798). 
Embora a federação canadense também adote um modelo dual, há uma inversão. As competências das províncias estão enumeradas nos 16 itens do art. 92 do Ato Constitucional de 1982. Cabem à União, por sua vez, 29 competências enumeradas, assim como as residuais, que abarcam tudo o que for necessário "para a paz, ordem e bom governo do Canadá". O mesmo esquema federal previu competências comuns no art. 95 do Ato Constitucional, estabelecendo, contudo, a preponderância da lei federal em caso de incompatibilidade com a legislação provincial. A federação canadense, por suas características, já mereceu a denominação de federalismo dualista com atenuação (CROISAT, 1992, p. 38).

b) Inserção dos direitos culturais indígenas na federação canadense

A perfeita compreensão do modo especial como se desenvolveu a relação jurídica e constitucional entre a Coroa Britânica, a França e os povos aborígenes do Canadá - as Primeiras Nações - exige um apanhado histórico de como ocorreu a colonização da América do Norte.

Em meados do século XVII e início do século XVIII, a América do Norte era palco de um iminente confronto entre as grandes potências da época. A colônia da Nova França se estendia desde o norte do Canadá, passando pela atual província de Ontário, cortava o território atual americano de norte a sul e finalmente alcançava a Louisiana. Geograficamente, a Nova França abraçava as 13 colônias britânicas que, no futuro próximo, dariam origem aos Estados Unidos (TAYLOR, 2001, p. 91).

Entre os dois territórios - a Nova França e as colônias britânicas -, havia nações indígenas poderosas que, com diferentes graus de intensidade, já negociavam com seus novos vizinhos. A chegada dos novos colonizadores modificou profundamente a cultura dos povos locais, com a introdução de animais então desconhecidos, armas de fogo e comércio entre as nações indígenas e as europeias. Na região da Nova França, foi notável o impacto causado pelo comércio de peles, que 
determinou cada vez mais a expansão das áreas de caça para o interior do continente (TAYLOR, 2001, p. 91).

A diferença demográfica entre a Nova França e as colônias britânicas era significativa: por volta do início do século XVIII, a Nova França contava com 75 mil habitantes, enquanto as 13 colônias já contavam com quase 1,5 milhão de pessoas (BORNEMAN, 2006). Naturalmente, essa disparidade demográfica determinava uma pressão para a ocupação das terras a oeste, e muitos colonos se especializaram na tarefa de prospectar, ocupar e negociar essas terras, na maior parte das vezes com os próprios povos indígenas.

A pressão pela ocupação do oeste, território ocupado por indígenas e franceses, desencadeou a Guerra Franco-Indígena, também lembrada no Canadá como a "Guerra dos Sete Anos" (1754-1763). De um lado, britânicos e colonos americanos; de outro, os franceses, contando com a ajuda de aliados indígenas (BORNEMAN, 2006).

Com a derrota dos franceses, chegava ao fim a soberania francesa na América do Norte. Através do Tratado de Paris, de 1763, selou-se o armistício, tornando-se a Nova França um território britânico.

No mesmo ano de 1763, foi emitida a Proclamação Real de 1763, um dos pontos cardeais do direito aborígene canadense. A Proclamação Real representou uma indicação do Império Britânico aos povos indígenas de que seus direitos territoriais seriam respeitados e de que a Coroa conteria o avanço da colonização. A proclamação atendeu ao objetivo de apaziguar os indígenas, declarando-os sob sua proteção e bloqueando a expansão para o oeste.

Com a Proclamação, a Coroa Britânica afirmou sua soberania sobre as terras conquistadas, proibiu a aquisição de terras pelos colonos diretamente dos índios e dispôs que as terras indígenas só poderiam ser ocupadas caso consensualmente cedidas à Coroa, e apenas à Coroa. Qualquer negociação dependeria da intervenção e licença da Coroa, para evitar acusações de trapaças ou negócios contrários aos interesses dos índios. Na lição de Robert Williams Jr.(1990, p. 238), 
A proclamação assinalou uma mudança significativa na prática anterior da Coroa com relação às colônias. Historicamente, Londres concedera às colônias uma relativa amplitude de discricionariedade e iniciativa ao lidar com as questões indígenas. Mas a guerra com os índios e os franceses alterou a perspectiva de Londres sobre a política imperial na América. A Inglaterra havia lutado e vencido uma guerra longa e cara pelo controle do Velho Noroeste. A proclamação era a instalação jurídica do controle político da Coroa sobre esse novo território adquirido como resultado da guerra.

O resultado direto da proclamação foi uma sensação de confinamento nos habitantes das 13 colônias, que há anos já vinham negociando terras e expandindo seus limites para o oeste. Para os colonos americanos, a proclamação representou um abuso dos seus direitos naturais de cultivar as terras e negociar diretamente com os indígenas locais, um renascimento do normanyoke, do jugo normando, a ideia que identificava a opressão britânica com a invasão normanda de 1066, que teria suprimido a liberdade idealidade da cultura anglo-saxã (WILLIAMS JR., 1990, p. 233). O cenário de insatisfação que resultaria na Revolução Americana estava preparado: de um lado, o bloqueio da expansão para o oeste; de outro, o arrocho fiscal destinado a pagar os custos da guerra que se encerrava.

A Proclamação de 1763, aliada às práticas e costumes que surgiram do contato com os colonizadores europeus a partir do século $\mathrm{XVII}$, deu lugar à doutrina dos direitos aborígenes. Desde os primeiros contatos entre europeus e indígenas, a prática da Grã-Bretanha foi a de celebração de tratados e acordos, reconhecendo a legitimidade das nações originárias para figurarem no polo desses acordos. Os tratados se prolongaram desde a data da Proclamação, continuaram após a confederação das províncias canadenses, ocorrida em 1867, até 1920, e foram retomados na década de 1970, após a decisão Calder (McNEIL, 2009). Justamente por isso, ao constitucionalizar os direitos aborígenes em 1982, na seção 35, o Ato Constitucional Canadense garantiu proteção aos direitos aborígenes e aos direitos decorrentes 
dos tratados celebrados ao longo dos anos. Nos seus termos exatos, a célebre seção 35 do Ato Constitucional de 1982 dispõe que "os direitos indígenas existentes e decorrentes de tratado dos povos aborígenes do Canadá são reconhecidos e afirmados".

Constitucionalizados os direitos tradicionais indígenas, a questão que se impunha era como compatibilizá-los com um sofisticado esquema de repartição de competências. Na lição de Slattery (1992), quatro princípios orientaram a inserção dos direitos tradicionais indígenas na federação canadense. Em primeiro lugar, a esfera aborígene de autoridade decorrente da seção 35 é coextensiva com os poderes federais reconhecidos na seção 91 (24) do Ato Constitucional de 1982, que reconhece à União o poder de legislar sobre os índios e a reserva de terras para os povos indígenas. Em segundo lugar, dentro dessa esfera, os governos aborígenes e o governo federal possuem poderes legislativos concorrentes. Em terceiro lugar, no caso de conflito entre leis aborígenes e legislação federal promulgada de acordo com a seção 91, as normas aborígenes válidas (incluindo normas costumeiras) terão prevalência, exceto nos casos em que a lei federal possa ser justificada sob a seção 35. Por fim, em quarto lugar, com relação às leis provinciais, as normas aborígenes têm o mesmo status que as leis federais editadas de acordo com a seção 91(24) (SLATTERY, 1992, p. 261).

Como se pode observar da lição de Brian Slattery (1992), o reconhecimento de certa "esfera legislativa" em favor das comunidades aborígenes se apoia em dois dispositivos constitucionais: o primeiro, o reconhecimento dos costumes e cultura indígenas; o segundo, a competência federal para legislar sobre assuntos indígenas, até mesmo limitá-los ou restringi-los de acordo com o Caso Sparrow, que especificou, no Direito canadense, as circunstâncias em que direitos dessa natureza poderiam ser restringidos ou limitados.

\section{Federação e povos indígenas no Brasil}

A história da colonização e a história constitucional brasileira apresentam semelhanças e diferenças significativas em relação à 
experiência canadense. No entanto, o texto constitucional brasileiro atual, a Constituição de 1988, consagra um modelo de federação semelhante, de corte cooperativo, ao mesmo tempo em que afirma, em termos tão claros quanto os empregados no Ato Constitucional Canadense, o reconhecimento constitucional dos direitos indígenas. Diante dessas aproximações e diferenças, é viável uma análise conjunta, buscando identificar se as conclusões levadas a efeito pela Suprema Corte Canadense a respeito do status constitucional das normas indígenas podem ser reproduzidas aqui.

a) Esquema institucional da federação brasileira

A Constituição Brasileira de 1988 insere-se no contexto histórico de modernos textos constitucionais que, inspirados pelas experiências cooperativas, adotaram uma modalidade de federação mais flexível, contemplando competências concorrentes.

A Constituição de 1988 adotou uma técnica de diferentes combinações de competências, combinando praticamente todos os arranjos já experimentados em outras nações (ALMEIDA, 2000, p. 74).

Ela fixou competências privativas, que se repartem de modo horizontal, e competências concorrentes, de repartição vertical, permitindo também a complementação da legislação do poder central pelos poderes periféricos, mediante delegação. As competências executivas e legislativas próprias da União foram elencadas nos artigos 21 e 22, respectivamente. Os Estados, por seu turno, receberam competências exclusivas, privativas e residuais, na forma do art. 25, reproduzindo o esquema norte-americano.

Os municípios, por fim, também receberam competências privativas, no art. 30 da Constituição Federal. O Distrito Federal, por expressa disposição constitucional, recebeu as competências atribuídas aos municípios e estados.

No plano vertical das competências comuns, o art. 23 previu as competências político-administrativas da União, estados, municípios e Distrito Federal, e o art. 24, a competência legislativa concorrente de 
União e estados. Na lição de Almeida, embora o município não esteja mencionado, sua participação na legislação concorrente pode ser extraída do art. $32, \S 2^{\circ}$, da Constituição, que lhe permite suplementar a legislação federal e estadual no que couber (ALMEIDA, 2000).

Por fim, a Constituição de 1988 prevê a possibilidade de delegação das competências legislativas exclusivas da União para os estados através de lei complementar autorizativa.

Segundo Almeida (2000), a inspiração da Constituição Brasileira é a Lei Fundamental de Bonn, de 1949, sobretudo pela divisão em competências legislativas e não legislativas da União em artigos distintos, separação das competências comuns em legislativas e não legislativas, previsão de delegação, repartição vertical da competência legislativa concorrente, cabendo as normas gerais à União e a legislação suplementar aos estados (ALMEIDA, 2000).

No caso concreto a que se propõe o presente trabalho, verifica-se que a competência legislativa relacionada com "populações indígenas" é exclusiva da União, conforme o art. 22, inciso XIV, da Constituição do Brasil. Cuidando-se de competência legislativa exclusiva da União, o parágrafo único do mesmo artigo permite autorizar os estados, por lei complementar, a legislar sobre questões específicas das matérias relacionadas neste artigo.

Os direitos indígenas, por seu turno, encontram amparo no art. 231 da CF/88: "são reconhecidos aos índios sua organização social, costumes, línguas, crenças e tradições, e os direitos originários sobre as terras que tradicionalmente ocupam, competindo à União demarcá-las, proteger e fazer respeitar todos os seus bens".

A questão que se impõe, em paralelo com a federação canadense, é, em primeiro lugar, que esfera, dentre as contempladas na federação brasileira, poderia, em tese, restringir ou modificar tradições ou costumes indígenas; e, em segundo lugar, se as tradições indígenas ou costumes se imporiam às demais esferas federais. É o que se propõe na seção seguinte do artigo. 
b) Inserção dos direitos culturais indígenas na federação brasileira

O Direito brasileiro não conheceu uma doutrina de direitos indígenas nos mesmos moldes da common law, tradição a que pertence - Canadá. Embora a Constituição Federal tenha reconhecido no Brasil o direito dos índios às terras que tradicionalmente ocupam ${ }^{1}$, esse direito está intimamente vinculado ao instituto das reservas indígenas a serem demarcadas pela União Federal. No plano concreto, não houve, na colonização brasileira, a confluência de interesses que resultasse no surgimento de um direito não-positivo, misto, derivado das práticas entre colonizadores, indígenas e Estado, como ocorreu no Canadá. Em certo sentido, a experiência histórica brasileira se aproxima da australiana: o nativo não foi visto como um parceiro ou um aliado, senão excepcionalmente (MICHEL, 2010, p. 89). Na cosmovisão dos colonizadores brasileiros, os grupos indígenas representavam apenas uma comunidade em estágio civilizacional intermediário que poderia evoluir para os moldes europeus mediante assimilação e integração. Não obstante, a política de alianças que esporadicamente se concretizou no período colonial (ABREU, 1930) não resultou em algo parecido com o "intersocietallaw" a que se refere Brian Slattery (1992), existente no Canadá.

Apesar desse estranhamento entre a doutrina canadense e o Direito brasileiro, há temas que foram enfrentados por ambas as tradições.

Constituição de 1934: "Art. 129. Será respeitada a posse de terras de silvícolas que nelas se achem permanentemente localizados, sendo-lhes, no entanto, vedado aliená-las."; Constituição de 1937: "Art. 154. Será respeitada aos silvícolas a posse das terras em que se achem localizados em caráter permanente, sendo-Ihes, porém, vedada a alienação das mesmas."; Constituição de 1946: "Art. Será respeitada aos silvícolas a posse das terras onde se achem permanentemente localizados, com a condição de não a transferirem.", Constituição de 1967: "Art. 186. É assegurara aos silvícolas a posse permanente das terras que habitam e reconhecido o seu direito ao usufruto exclusivo dos recursos naturais e todas as utilidades nelas existentes."; Constituição de 1969: "Art. 198. As terras habitadas pelos silvícolas são inalienáveis nos termos em que a lei federal determinar, a eles cabendo a sua posse permanente e ficando reconhecido o seu direito ao usufruto exclusivo das riquezas naturais e todas as utilidades nelas existentes." 
Os estudos etnográficos, até a primeira metade do século $\mathrm{XX}$, apresentavam um retrato dos povos indígenas sem levar em consideração a variável do tempo, que naturalmente havia produzido transformações nas suas culturas. Na observação de Berkhofer (1978, p. 29),

Se os brancos do início da colonização inventaram uma concepção do índio e o seu significado fundamental através do imaginário, por que as gerações posteriores perpetuaram esta concepção e imaginário sem alterações básicas, embora os indígenas tenham se modificado? A resposta a essa questão deve ser buscada parcialmente no exato contraste pressuposto entre a sociedade indígena e branca, que deu origem à ideia de índio num primeiro momento. Na medida em que os brancos inicialmente viam os índios como uma antítese a eles mesmos, então civilização e indianidade (indianess) como eles definiram seriam sempre opostos. Nessa visão, apenas a civilização tem história e dinâmica, de modo que a indianidade deve ser concebida como a-histórica e estática. Se os índios se modificaram através da adoção da civilização como definida pelos brancos, então eles deixaram de ser índios de acordo com esta imagem, porque os índios eram reconhecidos por sua oposição aos brancos. Mudança em direção ao o que os brancos eram os tornava ipso facto menos índios.

Essa visão a-histórica dos povos nativos é notável no precedente YortaYorta, em que a Suprema Corte Australiana não Ihes reconheceu o título nativo por entender que a sua cultura indígena havia sido perdida, “levada pela maré da história" (MICHEL, 2010, p. 61). No mesmo sentido, na Suprema Corte Canadense, os precedentes mais restritivos quanto à possibilidade de evolução dos direitos tradicionais também acentuam uma visão atemporal da sociedade indígena. A esse respeito, o teste Van Der Peet é o melhor exemplo: exige-se, para o reconhecimento de um direito aborígene tradicional, que ele seja integral a uma cultura por ocasião do primeiro contato, que em alguns locais do Canadá ocorreu há mais de quatro séculos. 
Como ressaltado inicialmente, a discussão sobre esses temas na tradição da common law teve como palco as cortes e os seus precedentes; no Direito brasileiro, inserido noutra tradição, não houve o surgimento de uma doutrina do título nativo nesses mesmos moldes, o que não quer dizer que os temas destacados - a natureza do título, a tensão entre a visão atemporal e a evolução dos direitos aborígenes, entre identidade e transformação - não tenham sido enfrentados.

A história do reconhecimento do direito dos índios às terras confunde-se com a própria história fundiária do Brasil. Na sua primeira fase, essa história é uma extensão das reformas fundiárias ocorridas em Portugal a partir do século XIV. Como marco inicial, a Lei Régia das Sesmarias, promulgada em Santarém, em 28 de maio de 1375, no reinado de D. Fernando I, foi o primeiro passo da Coroa Portuguesa para enfrentar o despovoamento e incrementar a produção rural em Portugal. Segundo Cime Lima (1954), o instituto das sesmarias teve origem em duas instituições medievais: a communalia, terras comunais do município medieval, desfrutadas utisinguli pelos munícipes e atribuídas ad tempus, e o colonato adscritício, prática de entregar para cultivo as terras desaproveitadas pelos proprietários negligentes, cumulada à adscrição, que consistia na obrigação de lavrar as terras. Nesse formato original, a sesmaria envolvia tanto o domínio como a interferência na liberdade do sesmeiro, originada do colonato adscritício. Após a revisão por D. João I, que limitou o elemento de restrição de liberdade, as sesmarias foram incorporadas às Ordenações Afonsinas (1446/1448) e, posteriormente, às Manuelinas (1521) e Filipinas (1603), sendo mantida a obrigação de cultivo como condição resolutiva do domínio pelo sesmeiro. Segundo Cirne Lima, por ocasião das Ordenações Filipinas, o instituto das sesmarias já tinha se demonstrado incapaz de aumentar o cultivo e repovoar o campo.

No Brasil, a carta patente de Martin Afonso de Sousa, de 20 de novembro de 1530, continha as três cartas régias que lhe concediam, dentre outros poderes, o de tomar posse das terras que "descobrisse" e, ao mesmo tempo, conceder sesmarias das terras que achasse e se pudessem aproveitar. As terras estavam inicialmente sob a jurisdição 
eclesiástica da Ordem de Cristo, a quem era devido o pagamento de dízimo, mas os maninhos, terras virgens nunca lavradas ou aproveitadas, não podiam ser apossados pela Ordem de Cristo ou pelos donatários. De certo que, em comparação com outras colonizações, as terras brasileiras foram vistas, desde o século XVI, como não pertencentes a ninguém ou vacantes, podendo ser "descobertas" e apossadas. $\mathrm{O}$ regime das capitanias hereditárias, a partir de 1532, autorizava 0 donatário a conceder terras, exceto a si próprio, pelo prazo de 8 anos; os maninhos no interior das capitanias podiam ser concedidos na forma de sesmarias; quem eventualmente herdasse uma capitania deveria se desfazer da sesmaria.

Até então, o regime das sesmarias no Brasil seguia o modelo português, cujos objetivos eram, essencialmente, o povoamento e o cultivo, limitados às possibilidades do sesmeiro. Ofendia ao espírito originário da sesmaria portuguesa a possibilidade de se conceder a alguém terras que não pudesse cultivar. Com a criação do GovernoGeral, em 1548, e o Regimento de 17 de dezembro de 1548, o modelo de sesmarias no Brasil começa a se distanciar do modelo português. Com um "espírito latifundiário" (LIMA, 1954), desaparece a vedação da concessão de áreas superiores à capacidade de cultivo do sesmeiro e introduz-se a vinculação aos engenhos de açúcar e à construção de torres e fortes para defesa contra os indígenas. Na lição de Cine Lima (1954), "a concessão de sesmaria não mais é a distribuição compulsória, em benefício da agricultura, das nossas terras maninhas, ao tempo tributárias ao Mestrado de Cristo; antes reveste o aspecto de uma verdadeira doação de domínios régios, a que só a generosidade dos doadores serve de regra". O afastamento definitivo do modelo português de sesmarias se dá em 1695 com a imposição de foros, até então vedados. A imposição dos foros representou uma apropriação legal do domínio direto, convolando as sesmarias, então, em "meramente concessões administrativas sobre o domínio público, ainda que com o encargo de cultivo" (LIMA, 1954).

Com relação aos povos indígenas e suas terras, ao longo da história colonial brasileira, a prática consagrada era o aldeamento. No 
Brasil-Colônia, estava presente a visão da sociedade indígena como uma sociedade deficiente (BERKHOFER JR., 1978, p. 55), em estágio intermediário de desenvolvimento, que precisava ser assimilada, gerenciada e protegida. A Carta Régia de 10 de setembro de 1611, que "declarou a liberdade dos gentios no Brazil, exceto os capturados em guerra justa"2, embora tenha assegurado que "os gentios serão senhores de suas fazendas nas povoações, assim como o são na serra, sem lhes poderem ser tomadas, nem sobre elas se lhes fazer modéstia, ou injustiça alguma", impôs o modelo do aldeamento como o ideal. Determinou que fossem eleitos, dentre as autoridades locais, os capitães de aldeia dos ditos gentios, que iriam "ao Sertão persuadir os ditos gentios desçam abaixo, assim com boas palavras e brandura, como com promessas, sem lhes fazer força, nem moléstia alguma”. Mas adiante, a Carta determina que "vindo os tais gentios, o governador os repartirá em povoações de até trezentos casais, poucos mais ou menos, limitando-Ihes sítio conveniente, aonde possam edificar a seu modo, tão distante dos engenhos e matas do pau do Brasil, que não possam prejudicar a uma cousa ou outra". As terras a serem escolhidas para os aldeamentos seriam as que não estavam sendo aproveitadas pelos capitães.

De tudo, depreende-se que, pela Carta Régia, não houve um verdadeiro reconhecimento do direito dos indígenas às terras originalmente ocupadas; a posse original é vista pela Coroa Portuguesa como precária e transitória, refletindo a visão da época a respeito da sociedade indígena.

No mesmo sentido, o Alvará Régio de $1^{\circ}$ de abril de 1680 (ANTUNES, 1998, p. 173), apontado como o termo inicial do instituto do indigenato no Brasil, declarou que as sesmarias não poderiam afetar os direitos originários dos índios sobre suas terras:

Importante fonte de atos legislativos históricos portugueses: Disponível em: < http://iuslusitaniae. fcsh.unl.pt/Presentation.php>. Acesso em> 02 fev. 2015 
[...] E para que os ditos Gentios, que assim decerem, e os mais, que há de presente, melhor se conservem nas Aldeias: hey por bem que senhores de suas fazendas, como o são no Sertão, sem lhe poderem ser tomadas, nem sobre ellas se lhe fazer moléstia. E o Governador com parecer dos ditos Religiosos assinará aos que descerem do Sertão, lugares convenientes para neles lavrarem, e cultivarem, e não poderão ser mudados dos ditos lugares contra sua vontade, nem serão obrigados a pagar foro, ou tributo algum das ditas terras, que ainda estejão dados em Sesmarias e pessoas particulares, porque na concessão destas se reserva sempre o prejuízo de terceiro, e muito mais se entende, e quero que se entenda ser reservado $o$ prejuízo, e direito os Índios, primários e naturaissenhores delas. (Grifou-se).

Pela primeira vez, surge, ao menos na legislação colonial, a afirmação de que os indígenas possuem direitos primários e naturais sobre a terra, limitando, ao menos teoricamente, os demais direitos reais simultaneamente relacionados com a mesma terra, com origem nos poderes da Coroa. A Lei Pombalina de 6 de julho de 1755 confirma "[...] os índios no inteiro domínio e pacífica posse das terras... para gozarem delas por si e todos seus herdeiros".

A Carta Régia de 2 de dezembro de 1808, de Dom João VI, declarou como devolutas as terras conquistadas aos índios por guerra justa, sugerindo que as terras do indigenato não se confundiriam com as devolutas.

Ao final do período colonial, a concessão de novas sesmarias é suspensa (Resolução de 17 de julho de 1822) e, entre proclamação da independência e a Lei de Terras de 1850, a posse assume posição de relevo como o principal modo de ocupação das terras no Brasil. A Provisão de 14 de março de 1822, por seu turno, determinava que as posses cultivadas prevaleceriam sobre as sesmarias, determinando a sua demarcação.

Diante da insegurança resultante de uma ocupação fundiária baseada em sua maior parte nas posses, a Lei de Terras, de 18 de 
setembro de 1850 (Lei $n^{\circ}$ 601), reconheceu a aquisição da propriedade pela posse cultivada, instituiu um processo de legitimação, encerrou o regime de posses no Brasil e proibiu a ocupação de terras devolutas.

A partir da Constituição de 1934, as constituições brasileiras passaram a assegurar aos indígenas o direito à posse de suas terras, traduzindo-se em posse ou usufruto constitucional o antigo instituto do indigenato. O processo culmina com a Constituição de 1988, cujos artigos 231 e 232 foram vazados nos seguintes termos:

Art. 231. São reconhecidos aos índios sua organização social, costumes, línguas, crenças e tradições, e os direitos originários sobre as terras que tradicionalmente ocupam, competindo à União demarcá-las, proteger e fazer respeitar todos os seus bens.

$\S 1^{\circ}$ - São terras tradicionalmente ocupadas pelos índios as por eles habitadas em caráter permanente, as utilizadas para suas atividades produtivas, as imprescindíveis à preservação dos recursos ambientais necessários a seu bem-estar e as necessárias a sua reprodução física e cultural, segundo seus usos, costumes e tradições.

$\S 2^{\circ}$ - As terras tradicionalmente ocupadas pelos índios destinam-se a sua posse permanente, cabendo-lhes 0 usufruto exclusivo das riquezas do solo, dos rios e dos lagos nelas existentes.

$\S 3^{\circ}$ - O aproveitamento dos recursos hídricos, incluídos os potenciais energéticos, a pesquisa e a lavra das riquezas minerais em terras indígenas só podem ser efetivados com autorização do Congresso Nacional, ouvidas as comunidades afetadas, ficando-lhes assegurada participação nos resultados da lavra, na forma da lei.

$\S 4^{\circ}$ - As terras de que trata este artigo são inalienáveis e indisponíveis, e os direitos sobre elas, imprescritíveis.

$\S 5^{\circ}$ - É vedada a remoção dos grupos indígenas de suas terras, salvo, «ad referendum» do Congresso Nacional, em caso de catástrofe ou epidemia que ponha em risco sua população, ou no interesse da soberania do País, após deliberação do Congresso Nacional, garantido, em qualquer hipótese, o retorno imediato logo que cesse o risco. 
$\S 6^{\circ}$ - São nulos e extintos, não produzindo efeitos jurídicos, os atos que tenham por objeto a ocupação, o domínio e a posse das terras a que se refere este artigo, ou a exploração das riquezas naturais do solo, dos rios e dos lagos nelas existentes, ressalvado relevante interesse público da União, segundo o que dispuser lei complementar, não gerando a nulidade e a extinção direito a indenização ou a ações contra a União, salvo, na forma da lei, quanto às benfeitorias derivadas da ocupação de boa fé.

$\S 7^{\circ}$ - Não se aplica às terras indígenas o disposto no art. $174, \S 3^{\circ}$ e $\S 4^{\circ}$.

Art. 232. Os índios, suas comunidades e organizações são partes legítimas para ingressar em juízo em defesa de seus direitos e interesses, intervindo o Ministério Público em todos os atos do processo.

Em paralelo com a federação canadense, na Constituição Brasileira, estão presentes as duas condições para um tratamento assemelhado, reconhecendo-se que os costumes e tradições indígenas impõem-se à legislação produzida pelos poderes periféricos, estados ou municípios. As mencionadas condições são o reconhecimento constitucional dos costumes indígenas e a fixação da competência federal para legislar sobre assuntos indígenas. Daí se poderia extrair a conclusão de que, de fato, o direito aborígene poderia ocupar um espaço dentro do próprio concerto federativo brasileiro, embora essa conclusão provavelmente não tenha sido prevista pelo legislador constitucional de 1988.

As zonas de conflito são previsíveis e estão, sobretudo, na faixa das competências concorrentes entre União, estados, Distrito Federal e municípios. Com efeito, o exame do art. 24 permite identificar várias matérias cuja legislação periférica poderia, de alguma forma, restringir ou limitar tradições e costumes indígenas. Os principais pontos de conflito podem surgir, em primeiro lugar, na legislação ambiental, em razão de seu caráter concorrente (art. 24 da Constituição Federal), potencial fonte de conflitos entre a legislação estadual ou municipal e os interesses indígenas; e, em segundo lugar, na legislação protetiva da infância, por suas óbvias interferências no modo como as famílias, indígenas ou não, educam e protegem seus filhos. 
Nesse particular, reconhecendo-se que, horizontalmente, os estados, Distrito Federal e municípios não teriam competência para restringir ou limitar tradições e costumes indígenas, a consequência é o surgimento, ainda que involuntário, de uma esfera de autonomia quase-federal em favor dessas comunidades, consequência certamente inesperada e inusitada da técnica de federação adotada na Constituição de 1988.

Há, de fato, no Congresso Nacional, em tramitação desde 1991, projeto de lei que se destina a criar um "Estatuto das Sociedades Indígenas" (Projeto de Lei $n^{\circ} 2.057$, de 1991), o qual prevê, em seu art. $3^{\circ}$, que "as sociedades indígenas têm personalidade jurídica de natureza pública de direito interno e sua existência legal independe de registro ou qualquer ato do Poder Público" e que "as relações internas a uma sociedade indígena serão reguladas por seus usos, costumes, tradições" (art. 6º) (BARRETO, 2003). Sem entrar no mérito constitucional da proposta, o certo é que a federação brasileira, no seu perfil atual, já prevê espaço de autonomia legiferante próprio a essas comunidades, como se extrai da análise supra.

\section{Conclusão}

Há algumas décadas, o federalismo moderno dá mostras de evolução, contemplando formas mais convergentes com as necessidades e complexidades atuais. O modelo dualista americano, na sua origem, representava a melhor alternativa sob o ponto de vista histórico. As transformações que conduziram a um federalismo cooperativo, ou até mesmo nos casos de federalismos assimétricos, adaptaram o modelo dual inicial às novas necessidades. Esses modelos, entretanto, embora atualizados, continuam partindo de pressupostos legicêntricos ou legolátricos, para usar as expressões empregadas por Grossi, desprezando em alguns casos fontes legiferantes não-estatais. O reconhecimento de uma esfera de exclusividade legiferante não-estatal representa, no caso concreto e formal das competências constitucionais, de certa forma, a materialização do princípio do pluralismo cultural a que alude Cunha Filho (2004, p. 75), sintetizado na ideia de que não há, entre 
as diferentes culturas constituintes do cenário nacional, uma relação de hierarquia ou excludência. A experiência canadense de reconhecimento dos direitos culturais indígenas, amparada em dispositivos constitucionais semelhantes aos consagrados na Constituição de 1988, permite um exercício de analogia para transposição das soluções lá encontradas para o direito constitucional brasileiro. Como consequência, surge, ainda que de modo involuntário ou inesperado, uma esfera de competências próprias para as comunidades indígenas, extraída da interpretação sistemática do texto constitucional.

\section{Referências}

ABREU, Capistrano de. Os caminhos antigos e o povoamento do Brasil. Brasília: EDUNB, 1963.

ALMEIDA, Fernanda Dias Menezes de. Competências na constituição de 1988. São Paulo: Atlas, 2000.

ANTUNES, Paulo de Bessa. Ação Civil Pública, meio ambiente e terras indígenas. Rio de Janeiro: Lumem Juris, 1998.

ASCH, Michael; MACKLEM, Patrick. Aboriginal rights and canadian sovereignty: an essay on R. V. Sparrow. Alberta Law Review, EDMONTon, v. XXIX, n. 2, p. 498-517, 1991.

BARRETO, Hélder Girão. Direitos indígenas: vetores constitucionais. Curitiba: Juruá, 2003.

BERKHOFER JR., Robert F. The white man's Indian. New York: Randon House, 1978.

BORNEMAN, Walter R. The french \& indian war: deciding the future of North America. New York: Harper Collins, 2006.

BORROWS, John. Indigenous Legal Traditions in Canada. Washington University Journal of Law and Policy, New York, v. 19, p.167, 2005.

CROISAT, Maurice. Le fédéralisme dans les démocraties contemporaines. Paris: Montchrestien, 1992. 
CUNHA FILHO, Francisco Humberto. Direitos culturais como direitos fundamentais no ordenamento jurídico brasileiro. Brasília: Brasília Jurídica, 2000.

CUNHA FILHO, Francisco Humberto. Cultura e democracia na constituição federal de 1988: a representação de interesses e sua aplicação ao Programa Nacional de Apoio à Cultura - Pronac. 2004. 223 f. Tese (Doutorado em Direito). Recife/PE, UFPE, 2004.

GROSSI, Paolo. Mitologias jurídicas da modernidade. Florianópolis: Fundação Boiteux, 2007.

LIMA, Ruy Cirne. Pequena história territorial do Brasil: sesmarias e terras devolutas. Porto Alegre: Sulina, 1954.

MCNEIL, Kent. Judicial treatment of indigenous land rights in the common law world. In: RICHARDSON, Benjamin; IMAI, Shin; MCNEILL, Kant (Ed.). Indigenous peoples and the law: comparative and critical perspectives. Oxford and Portland: Oregon, 2009. p. 257-284.

MICHEL, Voltaire. Direitos ancestrais: direito à terra indígena no Canadá, Austrália e Brasil. Porto Alegre: Uniritter, 2010.

SLATTERY, Brian. First nations and the constitution: A question of Trust. Canadian Bar Review, Ontario, n.71, p. 261-93, 1992.

TRIBE, Lawrence H. American constitutional law. University Textbook Series, 2000.

TAYLOR, Alan. American colonies: the settling of North America. New York: Penguin Books, 2001.

WILLIAMS JR., Robert. The american indian in western legal thought. New York: Oxford University Press, 1990.

Recebido em: 27/04/2015

Aprovado em: 24/05/2015 